\title{
PENGEMBANGAN MEDIA 'ECONOMIC MONOPOLY' BERBASIS GAME UNTUK MATA PELAJARAN EKONOMI KELAS X SMAN 1 SINGOSARI
}

\author{
Endah Nur Amalina ${ }^{1}$, Ro'$^{\prime} u f a h$ Inayati $^{2}$ \\ ${ }^{1}$ Universitas Negeri Malang, endahnuramalina.ea@gmail.com \\ ${ }^{2}$ Universitas Negeri Malang, roufah.inayati.fe@um.ac.id
}

\section{DOI}

https://doi.org/10.26740/jupe.v9n3.p129$\underline{137}$

\author{
Article history \\ Received \\ 10 August 2021 \\ Revised \\ 15 August 2021 \\ Accepted \\ 17 August 2021
}

\section{How to cite \\ Amalina, E. N. \& Inayati, R. (2021). \\ Pengembangan Media 'Economic \\ Monopoly' Berbasis Game untuk Mata \\ Pelajaran Ekonomi Kelas X SMAN 1 \\ Singosari. Jurnal Pendidikan Ekonomi \\ (JUPE), 9(3), 129-137. \\ https://doi.org/10.26740/jupe.v9n3.p129- 137}

Kata Kunci: Media Pembelajaran, Economic Monopoly, Gamifikasi

Keywords: Learning Media, Economic Monopoly, Gamification

\section{Corresponding author}

Endah Nur Amalina

endahnuramalina.ea@gmail.com

\begin{abstract}
Abstrak
Media pembelajaran berbasis teknologi digital belum banyak dimanfaatkan dalam kegiatan pembelajaran ekonomi di SMA Negeri 1 Singosari. Media pembelajaran ekonomi yang digunakan oleh guru ekonomi SMA Negeri 1 Singosari, baik itu buku paket maupun power point, yang kurang memanfaatkan secara maksimal fasilitas dan potensi yang dimiliki di masa digitalisasi ini sehingga menghambat jalannya penyerapan ilmu oleh siswa. Peraturan sekolah yang tidak melarang siswa untuk membawa smartphone ke sekolah disertai dengan perkembangan media pengembang dan teknologi yang semakin maju bisa dijadikan sebagai kekuatan untuk meminimalisir hambatan tersebut. Tujuan dari penelitian dan pengembangan ini adalah untuk mengembangkan media pembelajaran "Economic Monopoly (Ecopoly)" berbasis game android untuk mata pelajaran ekonomi siswa kelas X di SMA Negeri 1 Singosari materi Bank Sentral, Sistem Pembayaran, dan Alat Pembayaran. Penelitian ini menggunakan metode R\&D yang mengacu pada model ADDIE. Media yang telah selesai dikembangkan divalidasi oleh ahli materi, ahli media, dan pengguna. Hasil validasi menunjukkan bahwa media pembelajaran Economic Monopoly (Ecopoly) dinyatakan 'Sangat Layak' digunakan sebagai media pembelajaran ekonomi materi bank sentral, sistem pembayaran, dan alat pembayaran yang nantinya dapat meningkatkan motivasi belajar
\end{abstract}

Abstract
Digital technology-based learning media has not been widely used yet
in SMA Negeri 1 Singosari. The economic subject learning process used
by the teachers in SMA Negeri 1 Singosari, in textbooks and
PowerPoint, does not maximize the facilities and potential available in
this digital era, hindering students' capability in learning well. The
school rules that do not prohibit students from bringing smartphones to
school and the development of media and technology can minimize the
obstacle. This research and development aim to develop an android
game-based learning media called "Economic Monopoly (Ecopoly)" for
10th grader economic subject of SMA Negeri 1 Singosari in some
chapters such as Sentral Bank, Payment Method, and Payment Tool. The
study design for this research is the R\&D method that refers to the
ADDIE model. The developed media later will be validated by the
subject expert, media expert, and the users. The final expert validation
result show that Economic Monopoly (Ecopoly), referred to as "Very
Worthy, " is used as an economic subject learning media for sentral
bank, payment method, and payment tool.

\section{Abstract}

Digital technology-based learning media has not been widely used yet in SMA Negeri 1 Singosari. The economic subject learning process used by the teachers in SMA Negeri 1 Singosari, in textbooks and PowerPoint, does not maximize the facilities and potential available in this digital era, hindering students' capability in learning well. The school rules that do not prohibit students from bringing smartphones to school and the development of media and technology can minimize the obstacle. This research and development aim to develop an android game-based learning media called "Economic Monopoly (Ecopoly)" for 10th grader economic subject of SMA Negeri 1 Singosari in some chapters such as Sentral Bank, Payment Method, and Payment Tool. The study design for this research is the R\&D method that refers to the ADDIE model. The developed media later will be validated by the result show that Economic Monopoly (Ecopoly), referred to as "Very bank, payment method, and payment tool 


\section{PENDAHULUAN}

Di era revolusi industri 4.0, teknologi digital berkembang sangat pesat hingga menembus batas ruang dan waktu. Kemajuan teknologi digital mendukung untuk meningkatkan kualitas media pembelajaran. Dengan meningkatnya kualitas media pembelajaran akan turut serta meningkatkan hasil belajar siswa. Smaldino, Lowther, \& Russel (2011) mengungkapkan bahwa guru di abad XXI perlu memanfaatkan teknologi untuk mengembangkan media pembelajaran agar pembelajaran berkualitas sehingga dapat memotivasi siswa selaras dengan potensi yang ada di era digital ini. Di dalam Final Report World Education Forum (UNESCO, 2015), UNESCO menyatakan bahwa teknologi digital dapat dimanfaatkan guru untuk meningkatkan kualitas generasi selanjutnya.

Namun, media pembelajaran berbasis teknologi digital belum banyak dimanfaatkan dalam kegiatan pembelajaran di SMA Negeri 1 Singosari. Berdasarkan observasi dan wawancara dengan siswa di SMA Negeri 1 Singosari, diketahui bahwa media pembelajaran yang sering digunakan oleh guru mata pelajaran ekonomi adalah media cetak berupa buku paket dan media elektronik berupa power point. Buku paket paling sering digunakan karena seluruh siswa memperoleh pinjaman buku pelajaran dari sekolah. Sedangkan, media pembelajaran berbasis digital yang digunakan adalah power point. Tetapi, tidak semua siswa dapat memahami materi tersebut secara mandiri karena slide power point hanya berisi poin-poin materi yang diajarkan sehingga tidak bisa dijadikan sebagai media tunggal. Slide power point memerlukan media lain untuk memperjelas dan membantu pemahaman siswa.

Demikian pula dengan buku paket. Meskipun di dalamnya memuat latihan soal, namun media ini tidak bersifat interaktif di mana siswa tidak bisa mendapatkan respon atau feedback secara langsung setelah mengerjakan soal-soal yang ada tersebut. Selain itu, buku paket yang tebal menyebabkan siswa jarang membacanya dan cenderung menyukai media yang praktis (Astuti, Dasmo, \& Sumarni, 2018).

Media power point yang berbasis teknologi digital ternyata tidak dapat dipahami oleh semua siswa secara mandiri dan buku paket yang tidak praktis untuk digunakan belajar di berbagai kesempatan. Padahal, pemilihan media pembelajaran yang tepat sesuai kebutuhan siswa dapat menciptakan kegiatan pembelajaran yang lebih berkualitas (Abidin, 2016). Penggunaan media pembelajaran yang tepat juga akan mendukung proses penyerapan ilmu menjadi lebih optimal (Maryani, 2016). Dengan demikian, dapat dikatakan bahwa penggunaan media pembelajaran yang tidak tepat dapat menghambat penyerapan ilmu oleh siswa.
Terhambatnya siswa dalam penyerapan ilmu ini ditunjukkan pada tingkat pemahaman siswa terhadap materi yang rendah. Contohnya, pada materi Bank Sentral, Sistem Pembayaran, dan Alat Pembayaran. Sebagaimana tertera pada kompetensi dasar 3.6 yaitu mendeskripsikan bank sentral, sistem pembayaran, dan alat pembayaran dalam perekonomian Indonesia. Pada materi tersebut, mayoritas siswa di kelas X IPS A belum mencapai kriteria ketuntasan minimal, yaitu dari 36 siswa hanya $28 \%$ yang berhasil mencapai KKM.

Salah satu jalan untuk meningkatkan kualitas pembelajaran yaitu dengan memanfaatkan teknologi digital untuk mengembangkan media pembelajaran digital yang praktis dan efektif (Rusman, Kurniawan, \& Riyana, 2011). Pemilihan media yang akan digunakan harus memerhatikan beberapa faktor, seperti kemampuan media untuk memberikan feedback dan memperhatikan fasilitas yang tersedia di sekolah (Arsyad, 2014). Hal ini berarti bahwa media berbasis teknologi yang akan dikembangkan sebaiknya memanfaatkan fasilitas yang ada dan dimiliki oleh setiap individu, baik guru maupun siswa. Teknologi digital yang dimiliki guru dan siswa serta dapat memberikan respon secara langsung dan cepat salah satunya adalah smartphone.

Smartphone berkaitan erat dengan sistem operasi atau Operating System (OS), yaitu sistem yang menjalankan perintah yang diinput oleh pengguna telepon pintar. Operating System berbasis Android merajai pasar penjualan mobile operating system di Indonesia. Pada tahun 2018 - 2019, persentase penjualan Android mencapai 92,3\% dari seluruh penjualan, dan hingga bulan Oktober 2020 telah mencapai 92,3\% (Statcounter Global Stats, 2020). Penjualan OS Android yang merajai pasar ini menjadi salah satu pertimbangan peneliti untuk mengembangkan media pembelajaran game berbasis Android.

Fakta di lapangan yang peneliti dapatkan melalui observasi dan wawancara, diketahui bahwa seluruh siswa SMA Negeri 1 Singosari memiliki serta membawa smartphone ke sekolah. Sekolah tersebut juga telah disediakan fasilitas hotspot untuk mengakses internet. Berdasarkan potensi dan masalah yang ada, peneliti tertarik untuk meneliti dan mengembangkan media pembelajaran ekonomi yang menggunakan fasilitas hotspot sekolah dan smartphone yang dimiliki siswa. Dengan demikian, fasilitas pendukung kegiatan pembelajaran yang disediakan sekolah dapat digunakan secara optimal.

Media pembelajaran berbasis game android yang akan peneliti kembangkan sesuai untuk menyajikan materi yang sarat akan definisi, tahapan, jenis, dan fungsi disertai dengan latihan soal. Wijayanti \& Nurseto (2016) menemukan bahwa media berbasis game dapat meningkatkan minat siswa untuk mempelajari ekonomi. 
Didukung oleh Nurisa \& Ghofur (2019) yang memperoleh peningkatan hasil post-test paska diimplementasikannya media edukasi berbasis game berbasis android. Penyajian materi Bank Sentral, Sistem Pembayaran, dan Alat Pembayaran ke dalam media game dapat membantu siswa untuk belajar dimana pun dan kapan pun sehingga hasil belajarnya juga akan mengalami peningkatan. Pierce (2019) telah membuktikan bahwa gamifikasi dalam pembelajaran akan meningkatkan hasil belajar dan partisipasi siswa.

Permainan Monopoli merupakan permainan papan yang telah dikenal luas di seluruh dunia. Game Monopoli sudah banyak dikembangkan menjadi media pembelajaran, termasuk mata pelajaran ekonomi. Contohnya, Amsyari (2013), Yuliaini (2015) dan (Isnaini, 2016) mengembangkan monopoli untuk mata pelajaran ekonomi materi akuntansi, sedangkan Pritandhari \& Ratnawuri (2018) mengembangkan untuk evaluasi materi ekonomi secara keseluruhan. Namun, belum ada yang mengembangkan game Monopoli ini secara digital khususnya untuk materi Bank Sentral, Sistem Pembayaran, dan Alat Pembayaran. Sriwahyuni \& Mardono (2016) mengembangkan media pembelajaran untuk materi Bank Sentral, Sistem Pembayaran, dan Alat Pembayaran berbentuk game edukasi namun berbasis komputer, bukan smartphone.

Pemaparan di atas, dapat diketahui bahwa terdapat kelemahan pada media pembelajaran ekonomi yang digunakan oleh guru ekonomi SMA Negeri 1 Singosari, baik itu buku paket maupun power point, yang kurang memanfaatkan secara maksimal fasilitas dan potensi yang dimiliki di masa digitalisasi ini sehingga menghambat jalannya penyerapan ilmu oleh siswa yang ditunjukkan oleh tingkat ketercapaian KKM yang rendah. Peraturan sekolah yang tidak melarang siswa untuk membawa smartphone ke sekolah disertai dengan perkembangan media pengembang dan teknologi yang semakin maju bisa dijadikan sebagai kekuatan untuk meminimalisir hambatan tersebut.

Berdasarkan pemaparan latar belakang tersebut, maka dilakukanlah penelitian dan pengembangan untuk mengembangkan media pembelajaran 'Economic Monopoly (Ecopoly)' berbasis game untuk mata pelajaran ekonomi kelas X di SMA Negeri 1 Singosari khusus untuk materi Bank Sentral, Sistem Pembayaran, dan Alat Pembayaran sehingga siswa dapat meningkatkan pengetahuanya dan berhasil mencapai kompetensi dasar yang harus dikuasai.

\section{METODE}

Penelitian dan pengembangan media pembelajaran ini menggunakan metode Research and Development (R\&D) yang mengacu pada model ADDIE (Sugiyono, 2017).
Penggunaan model tersebut berdasarkan pertimbangan manfaat produk sebagai media pembelajaran. Model ADDIE memiliki lima tahapan pengembangan utama, yaitu analysis, design, development, implementation, dan evaluation

Tahap analisis dilakukan dengan mengumpulkan data dan informasi tentang permasalahan yang terjadi di kelas $\mathrm{X}$ IPS A SMA Negeri 1 Singosari melalui observasi dan wawancara dengan perwakilan siswa serta guru ekonomi. Selanjutnya dilakukanlah pembuatan desain dan pengembangan media Ecopoly dengan menggunakan software Corel Draw X7, Sparkol Video Scribe, dan Construct 3.

Media Ecopoly yang telah selesai dikembangkan selanjutnya divalidasi oleh ahli materi yang berasal dari dosen dan guru ekonomi, serta ahli media. Kemudian, Ecopoly diujicobakan pada kelompok kecil yaitu lima orang siswa kelas X IPS A. Setelah dinyatakan layak, maka Ecopoly diujikan ke pengguna yaitu siswa kelas X IPS A SMA Negeri 1 Singosari dengan jumlah siswa 36 orang.

Teknik pengumpulan data yang digunakan dalam penelitian dan pengembangan ini yaitu dengan angket untuk mengumpulkan data dari pengguna, ahli materi, dan ahli media sebagai bahan evaluasi media pembelajaran yang dibuat. Data kuantitatif kemudian dianalisis dengan teknik analisis deskriptif. Rumus yang digunakan menganalisis data dari masing-masing validator dan pengguna adalah sebagai berikut:

$$
V-a h / V-m t / V-a u=\frac{T S}{T S m a k s} \times 100 \%
$$

Setelah masing-masing uji validasi diketahui hasilnya, peneliti melakukan uji validitas gabungan ke dalam rumus berikut:

$$
V=\frac{V-a h+V-m t 1+V-m t 2+V-a u}{4}=\cdots \%
$$

Keterangan:

$\mathrm{V}=$ Validitas gabungan

$\mathrm{V}$-ah/mt/au $=$ Validitas ahli media, ahli materi, dan pengguna

TS = Total skor yang dicapai (berdasarkan penilaian ahli media, ahli materi, atau pengguna)

TSmaks $\quad=$ Total skor maksimal

\section{HASIL DAN PEMBAHASAN \\ Hasil}

Ecopoly merupakan akronim dari Economic Monopoly, yaitu media pembelajaran ekonomi berbasis game yang dikembangkan dalam penelitian ini. Berikut ini merupakan hasil penelitian dan pengembangan media Ecopoly berdasarkan model ADDIE.

Tahap pertama yaitu analisis yang dilakukan melalui observasi di SMA Negeri 1 Singosari dan wawancara 
bersama dengan Ibu Siti Nur Khasanah selaku guru ekonomi kelas X dan perwakilan siswa-siswi kelas X IPS A. Observasi ditujukan untuk melihat lingkungan sekolah, jalannya proses pembelajaran ekonomi hingga menemukan permasalahan yang membutuhkan penyelesaian.

Observasi pertama dilaksanakan pada hari Rabu, 20 Januari 2021 di kelas X IPS A dengan jumlah siswa 36 orang. Namun, dikarenakan pandemi, siswa yang masuk hanya 50\%, yakni siswa dengan nomor absen ganjil. Observasi kedua, dilakukan pada hari Rabu, tanggal 27 Januari 2021. Dari kegiatan observasi diperoleh hasil yakni media pembelajaran yang digunakan oleh guru ekonomi adalah power point dan buku paket. Selain itu, diketahui bahwa pada awal pembelajaran, seluruh siswa memperhatikan dengan seksama. Namun, seiring berjalannya waktu, siswa mulai kehilangan konsentrasi. Terdapat 13 dari 18 orang di observasi pertama, dan 14 dari 18 siswa di observasi kedua yang bermain smartphone serta berbincang-bincang dengan temannya.

Seusai mengamati jalannya kegiatan pembelajaran, dilanjutkan dengan wawancara dengan guru ekonomi. Beberapa pertanyaan yang diajukan yakni terkait media pembelajaran yang digunakan, respon siswa terhadap media yang digunakan, dan permasalahan yang dihadapi selama proses pembelajaran ekonomi. Selain itu, penulis juga menanyakan terkait regulasi sekolah dan fasilitas yang diberikan sekolah pada siswa dengan tujuan untuk mengetahui potensi dan kondisi sekolah.

Kegiatan wawancara tersebut dapat diperoleh informasi yakni guru menggunakan buku paket dan power point sebagai media pembelajaran, belum memanfaatkan media lain yang memanfaatkan teknologi, khususnya berkaitan dengan internet dan smartphone. Penggunaan media tersebut mengharuskan siswa selalu membawa buku paket dan mencetak materi di power point, sehingga kurang efesien untuk mendukung siswa belajar di manapun dan kapanpun. Siswa sendiri juga kurang memahami materi di power point karena memang hanya berisi poin-poin penting dari materi saja, tidak disertai dengan penjelasan yang luas.

Permasalahan yang dihadapi guru yakni siswa yang pasif dan seringkali tidak memperhatikan penjelasan guru. Siswa enggan bertanya bila ada materi yang tidak dipahami. Di tengah jam pelajaran, siswa sering mencuricuri waktu untuk bermain smartphone dan berbicara dengan temannya. Memang, sekolah tidak melarang siswa untuk membawa smartphone ke sekolah. Bahkan, sekolah telah menyediakan fasilitas hotspot agar siswa dapat mengakses internet dengan lancar.

Dilihat dari bentuk evaluasi pembelajaran, guru memberikan soal yang terdapat di buku paket maupun soal yang dibuat secara mandiri oleh guru dalam bentuk pilihan ganda maupun uraian. Proses koreksi dan penilaian dilakukan sendiri oleh guru kemudian nilainya dikembalikan pada siswa. Hal ini berarti siswa tidak dapat mengetahui secara langsung dimana letak kesalahannya dan seberapa jauh mereka berhasil memahami materi. Siswa harus menunggu untuk mengetahui berapa nilai yang diperolehnya.

Kemudian, dilanjutkan dengan wawancara bersama siswa tentang jalannya proses pembelajaran. Narasumbernya yaitu 12 orang perwakilan siswa kelas $\mathrm{X}$ IPS A. Hasilnya, lima orang menyatakan dapat memahami materi dan penjelasan guru dengan baik, dan sisanya belum memahami materi sepenuhnya karena media yang diberikan berbentuk power point yang tentunya hanya berisi poin-poin penting dari materi. Sedangkan, para siswa menyatakan jarang membaca buku paket karena berat dan membosankan.

Dengan demikian, dapat dinyatakan bahwa terjadi kesenjangan antara media pembelajaran yang digunakan dengan kebutuhan siswa, karakteristik siswa, dan perkembangan teknologi. Media pembelajaran yang digunakan guru ekonomi saat ini adalah buku paket dan power point. Media tersebut kurang relevan dengan kebutuhan dan karakteristik siswa di mana siswa membutuhkan media pembelajaran yang menarik, memotivasi, dan memudahkan pemahaman siswa. Selain itu, media tersebut juga kurang memanfaatkan kemajuan teknologi sehingga tidak mendukung siswa untuk belajar mandiri kapan pun dan di mana pun. Soal-soal evaluasi juga tidak memberikan hasil dengan cepat sehingga siswa harus menunggu untuk mengetahui hasil belajarnya. Dengan demikian, diperlukan media pembelajaran yang menarik, efisisen, dan sesuai dengan perkembangan teknologi.

Materi Bank Sentral, Sistem Pembayaran, dan Alat Pembayaran yang terdapat di dalam kompetensi dasar 3.6 dan 4.6 merupakan materi yang dikembangkan di dalam media Ecopoly. Materi tersebut memiliki karakteristik yaitu berisi konsep, pengertian, peran, fungsi, hingga tahapan-tahapan sehingga lebih menuntut siswa untuk menghafal. Berdasarkan hasil penilaian harian pada kompetensi dasar ini yang dilakukan oleh guru ekonomi, diketahui bahwa $72 \%$ siswa belum mencapai KKM senilai 75. Besarnya jumlah siswa yang belum mencapai tujuan pembelajaran ini salah satunya disebabkan oleh media pembelajaran yang digunakan. Oleh karena itu, diperlukan media yang menarik dan interaktif, disertai dengan latihan soal yang dapat memberikan feedback secara langsung.

Diizinkannya siswa-siswa SMA Negeri 1 Singosari untuk membawa smartphone ke lingkungan sekolah dan tingginya intensitas siswa dalam menggunakan smartphone menginspirasi peneliti untuk mengembangkan media pembelajaran yang dapat digunakan di dalam perangkat elektronik tersebut. 
Tahap desain dilaksanakan dengan merancang konsep media yang akan dikembangkan beserta layout penyajian materi di dalam aplikasi. Peneliti menentukan media yang akan digunakan yaitu berbentuk game dengan mengadaptasi permainan Monopoly yang sudah tidak asing bagi siswa. Media pembelajaran ini dinamakan Ecopoly yang merupakan singkatan dari Economic Monopoly. Nama Economic Monopoly secara filosofis memiliki makna yaitu siswa diibaratkan sebagai petualang yang mengelilingi dunia untuk memperoleh kekayaan berupa ilmu pengetahuan. Makna filosofis ini sejalan dengan teori konstruktivistik di mana siswa diberikan otoritas untuk membangun pengetahuannya sendiri (Dahar, 2011).

Materi pembelajaran Bank Sentral, Sistem Pembayaran, dan Alat Pembayaran akan disajikan ke dalam tiga bentuk, yaitu peta konsep, materi pembelajaran disertai ilustrasi, dan video pembelajaran. Harapannya, siswa dengan gaya belajar audiovisual, audio, maupun visual dapat belajar dengan nyaman dan menyenangkan.

Pada tahap ini, peneliti melakukan pembuatan dan pengembangan media pembelajaran dan melakukan validasi. Pengembangan media diawali dengan membuat layout untuk masing-masing menu menggunakan software Corel Draw X7. Selain layout, juga dilakukan desain asset atau item-item yang akan digerakkan di dalam permainan monopoli. Selanjutnya, dilakukan pembuatan materi dalam bentuk peta konsep, video, dan teks. Materi berupa teks dan ilustrasi, serta peta konsep dibuat dengan software Corel Draw X7. Sedangkan video pembelajaran dibuat dengan menggunakan software Sparkol Video Scribe. Setelah semua bahan atau asset lengkap, maka dilakukan pembuatan game dengan menggunakan software Construct 3. Dengan software tersebut, bahan-bahan media yang sudah dibuat dijalankan sesuai dengan alur yang diinginkan.

Media pembelajaran Ecopoly berbentuk file aplikasi yang dapat diunduh melalui link Google Drive. Ketika link tersebut diklik, maka smartphone android akan otomatis mengunduh dan menginstal media Ecopoly. Ketika aplikasi Ecopoly dibuka, maka siswa akan masuk pada menu utama. Di dalam menu utama terdapat enam pilihan fitur, yaitu Kompetensi Dasar, Tujuan Pembelajaran, Ayo Belajar, Ayo Bermain, Profil Pengembang, dan Tampilkan Bantuan (Gambar 1).

Menu 'Kompetensi Dasar' sebagaimana gambar 1 berisi kompetensi yang harus dikuasai siswa dalam mempelajari materi ini. Kompetensi yang harus dikuasai siswa yaitu kompetensi dasar 3.6 dan 4.6 di mana siswa harus dapat mendeskripsikan dan menyajikan peran bank sentral, sistem pembayaran, dan alat pembayaran dalam perekonomian Indonesia. Menu 'Tujuan Pembelajaran' berisi tujuan dipelajarinya materi bank sentral, sistem pembayaran, dan alat pembayaran pada kompetensi dasar 3.6 dan 4.6 ini.

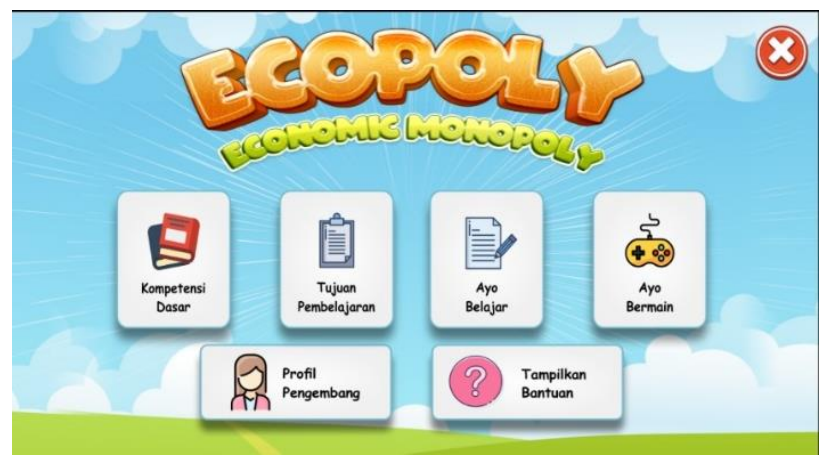

Gambar 1. Menu Utama Aplikasi Ecopoly

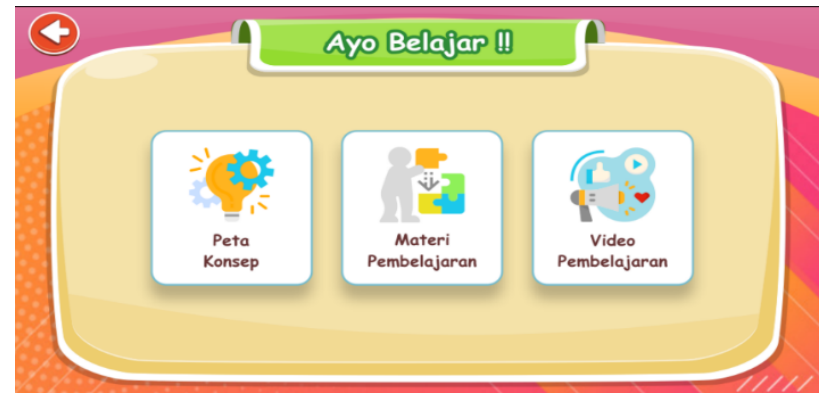

Gambar 2. Menu Ayo Belajar

Pada menu 'Ayo Belajar' disajikan tiga jenis pilihan media pembelajaran (Gambar 2), yaitu peta konsep, materi teks, dan video pembelajaran. Siswa dapat memilih sesuai dengan tipe gaya belajarnya.

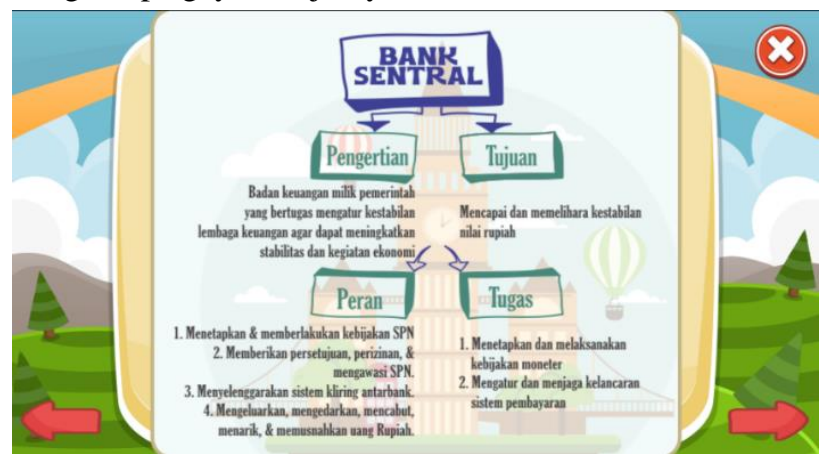

Gambar 3. Tampilan Peta Konsep

Pada menu 'Peta Konsep' materi disajikan dalam bentuk poin-poin dalam satu layar (Gambar 3). Setiap layar berisi satu materi pokok, yaitu bank sentral, sistem pembayaran, dan alat pembayaran.

Pada menu 'Materi Pembelajaran', materi disajikan salam bentuk teks disertai gambar ilustrasi pendukung (Gambar 4). Pemberian gambar dan penyajian materi dalama bentuk teks ditujukan untuk siswa khususnya yang memiliki gaya belajar visual, di mana siswa dapat belajar dengan membaca dan melihat gambar yang relevan dengan materi yang disajikan. 


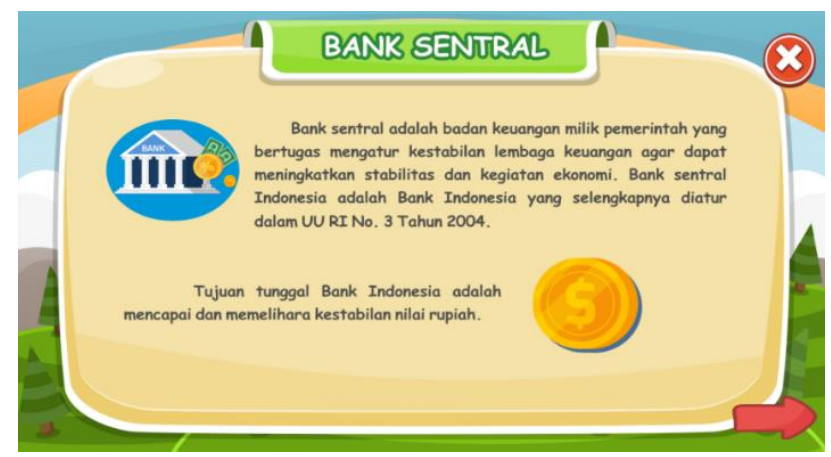

Gambar 4. Tampilan Materi Bank Sentral

Pada menu 'Video Pembelajaran' ditampilkan tiga pilihan materi pembelajaran yang akan dipelajari, yaitu bank sentral, sistem pembayaran, dan alat pembayaran. Siswa dapat memilih materi mana yang terlebih dahulu ingin dipelajari. Ketika pilihan materi diklik, siswa dapat langsung menyaksikan video pembelajaran yang disediakan (Gambar 5).

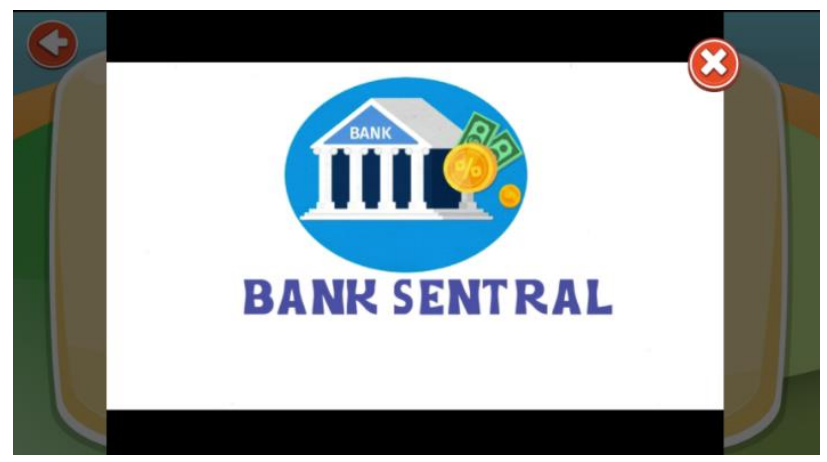

Gambar 5. Tampilan Video Bank Sentral

‘Ayo Bermain' merupakan menu yang berisi soal-soal evaluasi pembelajaran yang dikemas dalam bentuk game monopoli (Gambar 6). Pada menu ini ditampilkan dua pilihan submenu, yaitu 'Langsung Bermain' dan 'Petunjuk Permainan'. Siswa harus membaca petunjuk permainan terlebih dahulu untuk mengetahui bagaimana cara memainkan game ini beserta poin penilaiannya. Setelah selesai membaca petunjuk permainan, siswa dapat mengklik tanda centang yang berada pada sisi kanan bawah dan otomatis siswa akan kembali ke menu 'Ayo Bermain' dan melanjutkan dengan mengklik 'Langsung Bermain'.

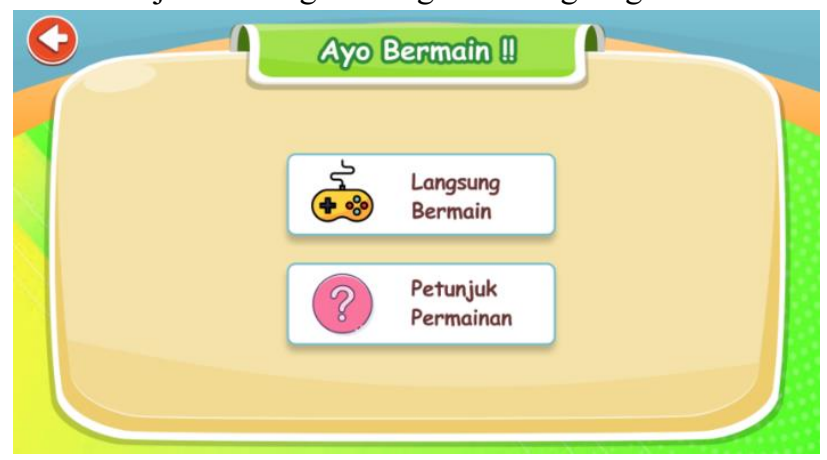

Gambar 6. Tampilan Menu Ayo Bermain
Ecopoly ini dimainkan oleh dua orang siswa secara berpasangan. Sebelum bermain, siswa harus menuliskan namanya masing-masing pada kolom yang tersedia. Setelah itu, akan muncul nama siswa yang telah diisikan dan urutan siapa yang akan melempar dadu terlebih dahulu.

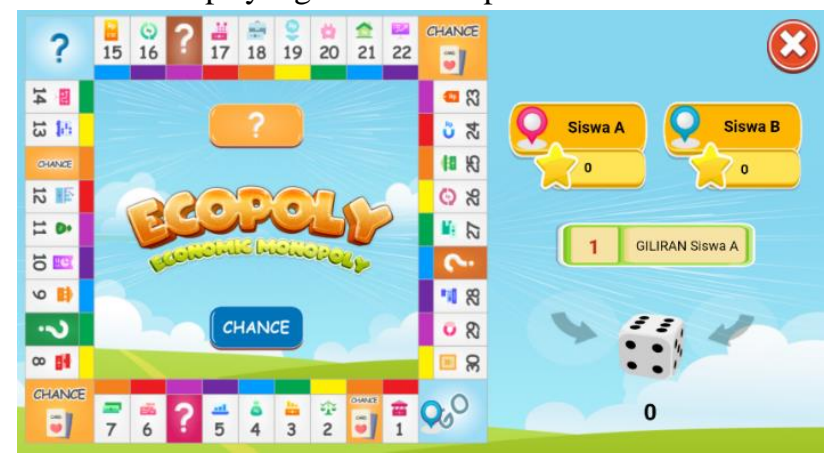

Gambar 7. Tampilan Papan Ecopoly

Selanjutnya, siswa yang mendapat urutan pertama melempar dadu dengan cara mengklik gambar dadu dan akan muncul berapa perolehan angka dari dadu yang dilempar (Gambar 7). Setelah itu, pion akan otomatis melangkah sesuai dengan jumlah angka yang keluar pada pelemparan dadu.

Ketika pion berhenti di salah satu angka, akan muncul pilihan soal A dan soal B dengan materi dan bobot yang sama. Pemberian pilihan soal A dan soal B ditujukan agar ketika siswa berhenti di nomor yang sama dapat menjawab soal yang berbeda. Soal akan muncul setelah siswa memilih untuk menjawab soal A atau soal B (Gambar 8). Ketika siswa menjawab benar, maka pilihan jawaban akan berubah warna menjadi hijau. Sedangkan, ketika siswa memilih jawaban yang salah, maka pilihan jawaban akan berubah menjadi merah dan pilihan jawaban yang benar tetap akan berubah warna menjadi hijau. Siswa yang menjawab benar akan mendapat poin 100 dan yang menjawab salah mendapat poin 0 .

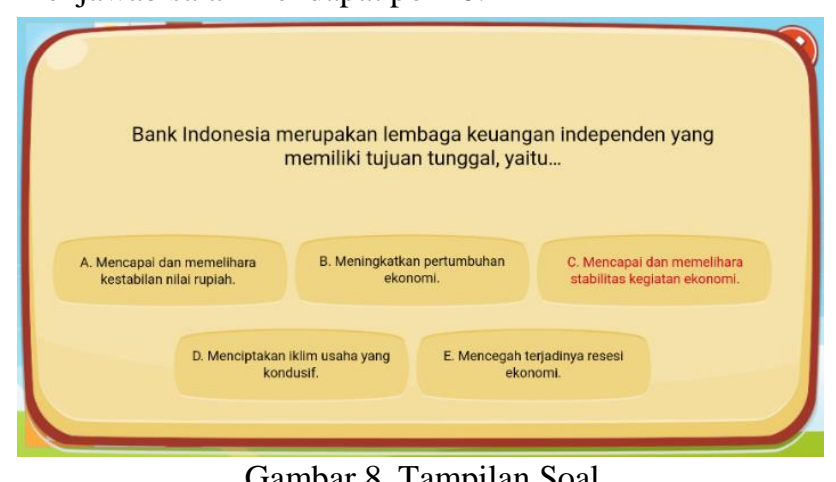

Namun, ketika pion berhenti pada gambar tanda tanya (?) atau fitur 'Tahukah Kamu?' maka akan muncul informasi terkait bank sentral, alat pembayaran, dan sistem pembayaran (Gambar 9). Setelah selesai membaca, siswa mengklik tanda centang dan kembali melanjutkan 
permainan. Pada pilihan 'Tahukah Kamu?' ini siswa tidak memperoleh poin. Saat pion berhenti pada gambar Chance, maka siswa otomatis akan mendapatkan bonus poin senilai 100 poin tanpa perlu menjawab soal.

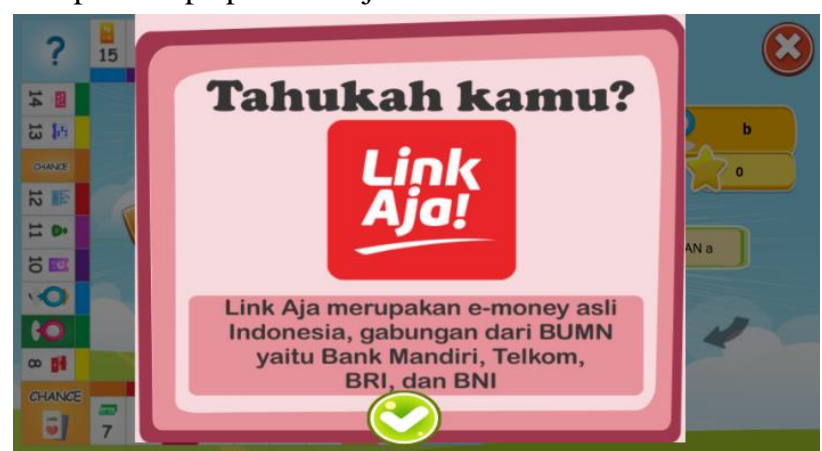

Gambar 9. Tampilan Menu 'Tahukah Kamu?'

Setelah salah satu pemain menyelesaikan satu putaran dan kembali ke garis start lebih dahulu, maka permainan berakhir dan akan muncul perolehan poin masing-masing pemain. Pemain yang mendapat poin lebih tinggi akan menjadi pemenangnya.

Pada menu 'Profil Pengembang' ditampilkan nama dan Riwayat hidup pengembang yang terdiri dari mahasiswa pengembang, dosen pembimbing, dan validator ahli materi serta ahli media (Gambar 10).

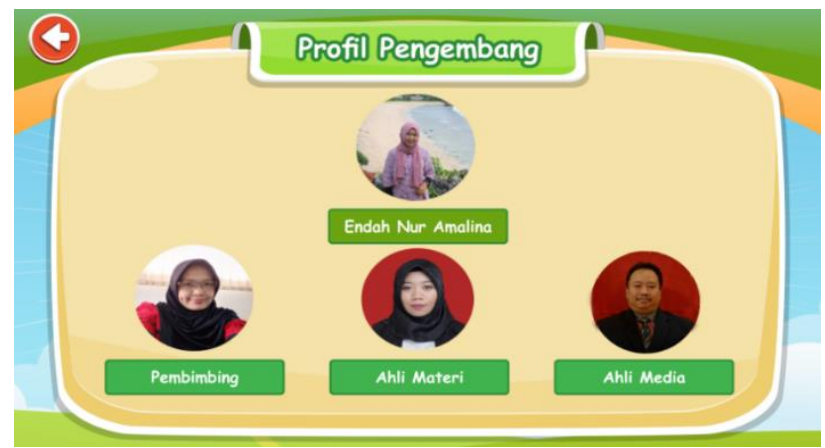

Gambar 10. Tampilan Profil Pengembang

Media pembelajaran Ecopoly yang telah selesai dikembangkan selanjutnya diujikan kepada ahli materi, dan ahli media. Validator ahli materi dari unsur dosen yaitu Ibu Vidya Purnamasari, S.E., M.Sc yang merupakan dosen jurusan Ekonomi Pembangunan, Fakultas Ekonomi, Universitas Negeri Malang. Sedangkan validator ahli materi dari unsur guru ekonomi adalah Ibu Siti Nur Khasanah yang merupakan guru ekonomi kelas X di SMA Negeri 1 Singosari. Validator ahli media yakni Bapak Henry Praherdhiono, S.Si., M.Pd yang merupakan dosen jurusan Teknologi Pendidikan, Fakultas Ilmu Pendidikan, Universitas Negeri Malang.

Validitas ahli materi dari unsur dosen diperoleh persentase sebesar 88,6\% dan guru ekonomi sebesar 95,6\% maka media pembelajaran game Ecopoly dari segi materi termasuk dalam kategori 'sangat layak' dan dapat diimplementasikan sebagai media pembelajaran ekonomi bagi siswa tanpa perbaikan. Berdasarkan validitas ahli media diperoleh persentase $97 \%$ yang berarti bahwa media pembelajaran Ecopoly berbasis game dari sudut pandang ahli media termasuk 'sangat layak' untuk diterapkan sebagai media pembelajaran ekonomi materi bank sentral, sistem pembayaran, dan alat pembayaran.

Sebelum media Ecopoly diujikan kepada seluruh siswa di kelas X IPS A, media diujikan dalam kelompok kecil yang terdiri dari lima orang siswa dan diperoleh persentase 96,7\% yang berarti media pembelajaran Ecopoly 'sangat layak' untuk diujicobakan pada kelompok besar.

Selanjutnya, dilakukan pengujian validasi kepada seluruh siswa di kelas X IPS A dengan jumlah 36 siswa. Hasilnya diperoleh persentase skor validitas pengguna sebesar $88,8 \%$. Dengan demikian, dapat diartikan bahwa media pembelajaran Ecopoly termasuk kategori 'sangat layak' untuk diimplementasikan sebagai media pembelajaran ekonomi di kelas X SMA Negeri 1 Singosari untuk materi bank sentral, sistem pembayaran, dan alat pembayaran.

Data validitas dari ahli materi dari unsur dosen dan guru, ahli media, dan siswa sebagai pengguna dianalisis secara gabungan dengan rumus sebagai berikut:

$V=\frac{V-a h+V-m t 1+V-m t 2+V-a u}{4}=\cdots \%$

$V=\frac{97+88,6+97+88,8}{4}=92,85 \%$

Berdasarkan analisis data validasi gabungan diperoleh hasil 92,85\% yang artinya media pembelajaran Ecopoly termasuk 'sangat layak' untuk digunakan sebagai media pembelajaran ekonomi kelas X materi bank sentral, sistem pembayaran, dan alat pembayaran.

Tahap evaluasi dilakukan melalui tiga langkah, yaitu menentukan kriteria evaluasi, memilih alat evaluasi, dan melaksanakan evaluasi. Kriteria evaluasi yang dipilih yaitu evaluasi persepsi untuk mengetahui respon siswa terhadap media pembelajaran Ecopoly. Hasil evaluasi digunakan oleh peneliti untuk memperbaiki media pembelajaran dan memenuhi kebutuhan yang belum dapat dipenuhi oleh media pembelajaran Ecopoly.

\section{Pembahasan}

Media pembelajaran ekonomi Ecopoly berbasis game untuk kelas X di SMA Negeri 1 Singosari telah melalui berbagai tahap validasi yang terdiri dari validasi ahli materi, ahli media, dan diujicobakan pada siswa sebagai pengguna. Hasil validasi dituliskan pada angket yang diberikan kepada validator dan dianalisis menggunakan rumus yang telah dipaparkan pada bagian sebelumnya. Seluruh hasil validasi diakumulasi dan dirata-rata hingga diperoleh validitas gabungan sebesar 92,85\%. Berdasarkan kriteria hasil validasi (Akbar, 2013), persentase 92,85\% 
termasuk dalam kategori 'sangat layak' untuk diterapkan sebagai media pembelajaran.

Media Ecopoly yang disajikan dalam bentuk game menarik perhatian siswa karena siswa terdorong untuk mempelajari materi terlebih dahulu sebelum memainkannya. Terbukti dari siswa yang membuka seluruh menu yang tersedia serta membaca dan menyaksikan materi yang disediakan.

Materi yang ada dikemas dalam bentuk peta konsep, video, dan teks yang dilengkapi dengan gambar ilustrasi sehingga siswa dapat mempelajari materi sesuai dengan gaya belajarnya. Dengan naiknya perhatian siswa untuk menggunakan media, maka diharapkan juga turut meningkatkan minat belajar siswa. Hal tersebut sesuai dengan Mardia (2017) yang menemukan bahwa media pembelajaran berbasis game dapat meningkatkan minat belajar siswa sebab kegiatan belajar menjadi lebih menyenangkan, kreatif, dan efektif. Wijayanti \& Nurseto (2016) juga membuktikan hal serupa, yakni media pembelajaran berbasis game dapat menaikkan minat belajar ekonomi siswa.

Game Ecopoly yang berbasis smartphone dapat menjadi alternatif media pembelajaran yang bisa digunakan siswa dimanapun dan kapanpun sehingga lebih praktis. Pada akhirnya, siswa dapat belajar secara mandiri, efektif, serta memanfaatkan perkembangan teknologi. Dengan demikian, penggunaan Ecopoly dapat mendukung siswa meningkatkan kemandirian belajar. Hal tersebut sejalan dengan Dewi (2020) yang membuktikan bahwa pengguna smartphone atau perangkat mobile dapat meningkatkan kemandirian belajar siswa bahkan dapat meningkatkan kemampuan berpikir siswa.

Game Ecopoly yang dimainkan secara berpasangan akan mendorong siswa untuk lebih bersemangat dalam belajar. Selaras dengan Huda (2013) bahwa metode belajar berpasangan akan meningkatkan respon siswa terhadap pertanyaan karena adanya konsep waktu berpikir. Siswa akan terpacu untuk belajar karena nanti akan bersaing dengan pasangannya. Siswa akan berusaha untuk memenangkan game dengan cara mempelajari materi dengan sungguh-sungguh sebelum bertanding. Hal ini didukung oleh De-Marcos, Garcia-Lopez, \& Garcia-Cabot (2016) yang menyatakan bahwa pembelajaran dengan game akan memotivasi siswa sehingga memicu partisipasi siswa untuk belajar dan melakukan interaksi sosial.

Pemaparan di atas menunjukkan bahwa media pembelajaran Ecopoly ini sangat layak untuk diimplementasikan sebagai media pembelajaran ekonomi di SMA Negeri 1 Singosari kelas $X$ khusus materi bank sentral, sistem pembayaran, dan alat pembayaran. Media pembelajaran Ecopoly berbasis game yang telah dikembangkan memiliki keunggulan sebagai berikut:
1. Ecopoly dapat diunduh otomatis melalui link yang dapat disebarluaskan melalui WhatsApp, e-mail, telegram, dan aplikasi untuk mengirim pesan lainnya, serta dapat disebarluaskan melalui aplikasi Share-it dan Bluetooth.

2. Ecopoly tidak memerlukan jaringan internet untuk pengoperasiannya sehingga dapat digunakan pada daerah dengan jaringan internet yang tidak stabil.

3. Ecopoly berbentuk game dan terinstall di dalam smartphone sehingga praktis untuk dibawa dan digunakan di mana saja.

4. Ecopoly dilengkapi dengan materi dan ilustrasi, video pembelajaran, dan peta konsep yang memfasilitasi siswa dengan berbagai gaya belajar.

5. Ecopoly menyajikan latihan soal dalam bentuk game yang dapat dimainkan secara berpasangan.

\section{SIMPULAN}

Berdasarkan pemaparan pada bagian hasil dan pembahasan, diperoleh validasi ahli materi dari unsur dosen diperoleh persentase sebesar $88,6 \%$ dan guru ekonomi sebesar $95,6 \%$, ahli media $97 \%$, pengguna $88,8 \%$, serta validasi gabungan $92,85 \%$. Dengan demikian, dapat disimpulkan bahwa media pembelajaran Ecopoly 'sangat layak' untuk diimplementasikan sebagai media pembelajaran ekonomi kelas X materi bank sentral, sistem pembayaran, dan alat pembayaran. Media Ecopoly yang berbasis game, dioperasikan melalui smartphone, serta materi yang disajikan dalam bentuk video, peta konsep, dan teks disertai gambar ilustrasi memudahkan siswa belajar sesuai dengan gaya belajarnya, mendorong siswa untuk belajar mandiri dan meningkatkan minat belajar siswa. Ecopoly yang dimainkan secara berpasangan meningkatkan semangat belajar siswa.

Namun, masih terdapat beberapa keterbatasan dari media Ecopoly yang telah dikembangkan dan direvisi, yakni:

1. Ecopoly hanya dapat dipasang pada smartphone dengan sistem operasi android minimal 4.4 kitkat dengan RAM minimal $2 \mathrm{~GB}$, serta resolusi layar minimal 720 x 1.280 pixel.

2. Ecopoly tidak dapat diinstal pada laptop maupun perangkat komputer secara langsung, tetapi memerlukan emulator, seperti Blue Stacks, YouWave, MEтu Emulator, dan software sejenis lainnya.

3. Ecopoly belum dapat diunduh melalui playstore dan hanya dapat disebarluaskan melalui link unduhan google drive.

Keterbatasan-keterbatasan pada Ecopoly dapat dijadikan bahan perbaikan sehingga disarankan bagi peneliti selanjutnya yang akan mengembangkan media pembelajaran sejenis diharapkan mengembangkan aplikasi untuk sistem operasi iOS serta laptop atau perangkat 
komputer tanpa harus memasang emulator. Ecopoly ini dapat dikembangkan untuk materi ekonomi lainnya dengan syarat memiliki karakteristik materi yang sama.

\section{DAFTAR PUSTAKA}

Abidin, Z. (2016). Penerapan Pemilihan Media Pembelajaran. Edcomtech Jurnal Kajian Teknologi Pendidikan, 1(1).

Akbar, S. (2013). Instrumen Perangkat Pembelajaran. Bandung: Rosdakarya.

Amsyari, Z. I. (2013). Pengembangan Media Pembelajaran Permainan Monopoli Akuntansi untuk Siswa SMA Negeri 1 Bangil (Universitas Negeri Malang). Universitas Negeri Malang. Diambil dari http://repository.um.ac.id/34652/

Arsyad, A. (2014). Media Pembelajaran Edisi Revisi. Jakarta: PT Rajagrafindo Persada.

Astuti, I. A. D., Dasmo, \& Sumarni, R. A. (2018). Pengembangan Media Pembelajaran Berbasis Android dengan Menggunakan Aplikasi Appypie di SMK Bina Mandiri Depok. Jurnal Pengabdian Kepada Masyarakat, 24(2).

Dahar, R. W. (2011). Teori-teori Belajar dan Pembelajaran. Bandung: Erlangga.

De-Marcos, L., Garcia-Lopez, E., \& Garcia-Cabot, A. (2016). On the effectiveness of game-like and social approaches in learning: Comparing educational gaming, gamification \& social networking. Computers and Education. https://doi.org/10.1016/j.compedu.2015.12.008

Dewi, I. M. R. (2020). Penggunaan Mobile Learning untuk Meningkatkan Kemandirian Belajar Peserta Didik Sekolah Menengah Atas. Edutech, 19(2), 214-228.

Huda, M. (2013). Model-Model Pengajaran dan Pembelajaran: Isu-Isu Metodis dan Paradigma. Yogyakarta: Pustaka Pelajar.

Isnaini, A. N. (2016). Pengembangan Media Pembelajaran Monopoli Akuntansi untuk Meningkatkan Motivasi Belajar Siswa Kelas X AK 2 SMK Negeri 4 Klaten Tahun Ajaran 2015/2016. Universitas Negeri Yogyakarta.

Mardia, A. (2017). Efektivitas Penggunaan Media Pembelajaran Monopoly Game Smart terhadap Minat Belajar Peserta Didik Pada Mata Pelajaran Fisika Kelas VIII SMPN 2 Baraka. UIN Alauddin Makassar.

Maryani, U. (2016). Pengelolaan Pembelajaran Ilmu Pengetahuan Alam di SD Melalui Media Sederhana. Manajer Pendidikan, 10(4), 386-391.

Nurisa, K., \& Ghofur, M. A. (2019). Pengembangan Media Pembelajaran Game Edukasi berbasis Android pada Mata Pelajaran Ekonomi Kelas X IPS SMA Negeri 1 Bangkalan. JUPE, 7(2), 38-43.

Pierce, K. R. (2019). The Wiley Handbook of Global Workplace Learning. In The Wiley Handbook of Global Workplace Learning. https://doi.org/10.1002/9781119227793

Pritandhari, M., \& Ratnawuri, T. (2018). Analisis Pembelajaran Monopoli Ekonomi (Monokomi)
Pada Siswa Boarding School. Jurnal PROMOSI, 6(2), 99-105.

Rusman, Kurniawan, D., \& Riyana, C. (2011). Pembelajaran Berbasis Teknologi Informasi dan Komunikasi. Jakarta: Rajawali Press.

Smaldino, S. E., Lowther, D. L., \& Russel, J. D. (2011). Instructional Technology and Media for Learning. London: Pearson.

Sriwahyuni, N. A., \& Mardono. (2016). Pengembangan Media Pembelajaran Game Edukasi Pada Mata Pelajaran Ekonomi Kelas X Iis Sma Laboratorium Universitas Negeri Malang. Jpe, 9(2).

Statcounter Global Stats. (2020). Mobile Operating System Market Share Indonesia Oct 2019 - Oct 2020. Diambil 28 November 2020, dari Statcounter Global Stats website: https:gs.statcounter.com

Sugiyono. (2017). Metode Penelitian Kuantitatif, Kualitatif, dan $R \& D$. Bandung: CV Alfabeta.

UNESCO. (2015). World Education Forum 2015 Final Report. Perancis.

Wijayanti, T., \& Nurseto, T. (2016). Pengembangan Media Game Ular Tangga Ekonomi untuk Meningkatkan Minat Belajar Ekonomi. Prosiding Seminar Nasional: Penguatan Hubungan antara Pengembangan Keterampilan, Pendidikan, dan Ketenagakerjaan Generasi Muda.

Yuliaini, E. (2015). Permainan Monopoli sebagai Media Pembelajaran Ekonomi Bagi Siswa Tingkat Sekolah Menengah Atas. In Indawan \& S. Ahmad (Ed.), Prosiding Seminar Pendidikan Nasional (hal. 1455). Palembang: Universitas PGRI Palembang. 